\title{
Observations on the Action of Benzylpenicillin on a Strain of Streptococcus lactis
}

\author{
By G. J. DRING AND A. HURST \\ Unilever Research Laboratory, Colworth House, Sharnbrook, Bedford
}

(Accepted for publication 19 September 1968)

SUMMARY

Streptococcus lactis was grown in media containing various concentrations of benzylpenicillin; $0.05 \mu \mathrm{g} . / \mathrm{ml}$. was without effect and $0.40 \mu \mathrm{g} . / \mathrm{ml}$. inhibited growth. Intermediate concentrations in increasing steps of $0.05 \mu \mathrm{g} . / \mathrm{ml}$. were investigated. The Gram-positive cocci tended to become Gram-negative rods, the most effective concentration of penicillin for this effect was $0.15 \pm 0.05$ $\mu \mathrm{g} . / \mathrm{ml}$. The rod forms frequently had surface vesicles which appeared to be membrane-bounded but were osmotically stable; the dry wt yield $/ \mathrm{ml}$. medium was diminished. Such forms contained up to Io times more nisin/unit dry wt than the control. At penicillin 0.20 to $0.25 \mu \mathrm{g}$. $/ \mathrm{ml}$. growth was followed by lysis which was followed by new growth after a long delay; morphologically these forms resembled the controls and the dry wt yield increased. Higher concentrations of penicillin $(0.35 \mu \mathrm{g} . / \mathrm{ml}$.) decreased the dry wt yield $/ \mathrm{ml}$. medium and growth appeared only after a delay of $\mathrm{I} 6 \mathrm{hr}$. Morphologically these forms tended to elongate again and the cell nisin/unit dry wt was 8 times higher than the control. Single-colony isolates obtained from the higher penicillin concentrations were grown in penicillin-free medium and when again challenged with penicillin no longer formed rods at $0.15 \mu \mathrm{g} . / \mathrm{ml}$. This more penicillin-resistant population occurred at a frequency of $1: 500$ of the parent population and was distinguished from it by a number of physiological properties. These results suggest that penicillin acted by selecting resistant individuals already present in the parent population.

\section{INTRODUCTION}

Previous studies on the synthesis and function of nisin, a basic protein with antibiotic activity, suggested that it plays a regulatory role concerned with the initiation and halting of growth of the organism which produces it. Hurst \& Dring (I968) showed that the length of lag phase of growth in Streptococcus lactis was directly related to the nisin content of the organism. White \& Hurst (I968) examined the location of nisin within cells of the producer organism and demonstrated that its principal association was with the wall and membrane. They fractionated cells by chemical and mechanical methods but were unable to obtain membranes free from contaminating wall material. Protoplasts would have provided ideal material for studies of the membrane-associated nisin but we were unable to produce them in preliminary studies. We tried unsuccessfully treatments with sodium lauryl sulphate, deoxycholic acid, glycine, lysozyme, snail and spore enzyme and mixtures of these reagents. We found that crude enzyme preparations from Streptomyces albus (Maxted, 1948) led to the total uncontrollable digestion of the organism and its structures. Brown, Sandine \& Elliker (1962) were able to lyse Streptococcus lactis and other lactic acid bacteria by 
digestion with lysozyme in the presence of EDTA at $\mathrm{pH} 8 \cdot 0$, but application of this method was undesirable since the antibiotic activity of nisin is lost in alkaline solutions.

Penicillin is known to affect the cell walls of sensitive bacteria and has been used for making protoplasts or spheroplasts (McQuillen, I960). We therefore tried the effect of penicillin on our strain of Streptococcus lactis which is highly penicillin-sensitive. Although we have not succeeded in obtaining protoplasts we have obtained unexpected results. With increasing concentrations of penicillin in the culture medium the terminal dry-weight yield of organism did not decrease proportionately with the penicillin concentration over the range examined. The data suggested that the parent strain contained some individuals of higher penicillin-resistance (type II culture). Some of the physiological properties of the parent strain and of the type II culture derived from it were studied; first, by testing the effect of increasing concentrations of penicillin on the dry-weight yield, morphology and nisin content; secondly by testing the effect of increasing concentrations of penicillin on growth kinetics. We then isolated a pure clone of the type II culture and compared the heat and acid tolerance of the parent with the type II cultures. A preliminary account of this work has already been published (Dring \& Hurst, 1967).

\section{METHODS}

Organism. Streptococcus lactis 354/07 (NCDO 497) was used throughout; it was maintained on slopes at $2^{\circ}$ prepared from a culture derived from a single-colony isolate.

Morphology. Cell morphology was examined and photographed by using a Zeiss photomicroscope fitted with phase-contrast. For electron microscopy, organisms were fixed and stained according to the method of Hamilton \& Stubbs (1967). Sections were made on a L.K.B. Ultratome III and examined in a J.E.M. 7 A electron microscope.

Medium and estimation of minimum inhibitory concentration. All cultivation was done in the medium of Hurst (1966) used either as a liquid or solidified with agar; it had the following composition ( $\%, \mathrm{w} / \mathrm{v})$ : meat extract (Lemco), I; yeast extract (Difco), I ; tryptone (Difco), $\mathrm{I} ;$ glucose, $\mathrm{I} ; \mathrm{NaCl}, 0.5 ; \mathrm{Na}_{2} \mathrm{HPO}_{4}, 0.2 ; \mathrm{pH} 7$; solidified when required with Agar (Difco), I.5.

For the determination of the minimum inhibitory concentration (m.i.c.) of benzylpenicillin (Penicillin, sodium salt of crystalline benzylpenicillin; Crystapen, Glaxo Laboratories, England) against the organism, cultures were grown for $18 \mathrm{hr}$ at $30^{\circ}$ and were then inoculated at $0.1 \%(\mathrm{v} / \mathrm{v})$ into liquid medium containing penicillin graded in increments of $0.05 \mu \mathrm{g} . / \mathrm{ml}$. over the range 0.05 to $0.40 \mu \mathrm{g} . / \mathrm{ml}$. Only fresh penicillin solutions were used; they were prepared at a concentration of $50 \mu \mathrm{g} . / \mathrm{ml}$. in distilled water, sterilized by Seitz filtration and diluted in the growth medium as required.

Estimations. The growth response of the organism at the various concentrations of penicillin was determined by measuring the extinction of growing cultures at $600 \mathrm{~m} \mu$ in a Unicam SP 600 spectrophotometer (Unicam Instruments, Cambridge, England) against distilled water in $3.0 \mathrm{ml}$. cuvettes with $\mathrm{I} \mathrm{cm}$. light path, and by gravimetric determination of terminal organism dry weights. $\mathrm{pH}$ values were determined electrometrically and nisin by bioassay (Hurst, 1966).

Most probable numbers. The number of type II organisms in the parent population was estimated by diluting an overnight culture in decimal dilution series to $\mathrm{ro}^{-9}$ organisms $/ \mathrm{ml}$. and pipetting $5 \times 1 \cdot 0 \mathrm{ml}$. samples of each dilution to $9.0 \mathrm{ml}$. volumes of 
liquid medium with and without $0.25 \mu \mathrm{g}$. penicillin $/ \mathrm{ml}$. The tubes were incubated at $30^{\circ}$ for $48 \mathrm{hr}$ and most probable number (m.p.n.) were estimated from probability tables. Those organisms developing in medium containing penicillin were scored as type II organisms.

Acid and heat tolerance test. An overnight culture was harvested, washed and the organisms were resuspended at $10^{7}$ viable organisms $/ \mathrm{ml}$. For the heat test the organism was resuspended in fresh medium held at $60^{\circ}$. For the acid test the organism was resuspended in distilled water or $0.04 \mathrm{~N}$-lactic acid held at $37^{\circ}$. Exposure of the organism to heat or acid was continued until the viable count decreased from $10^{7}$ to about $10^{5}$ organisms/ml., numbers being estimated by surface plating (Miles \& Misra, I938). When this decrease in number was achieved the colonies which developed were screened for penicillin resistance. Discrete colonies were picked with sterile hypodermic needles and replicated by touching the surface of agar medium containing penicillin $(0.00$ to $0.5 \mu \mathrm{g} . / \mathrm{ml}$.). The plates were incubated at $30^{\circ}$ for $48 \mathrm{hr}$ and the number of developing colonies at each concentration of penicillin counted.

\section{RESULTS}

Effects of penicillin, added at time of inoculation, observed in cultures which had reached stationary phase

\section{Minimum inhibitory concentration}

Penicillin at $0.40 \mu \mathrm{g} . / \mathrm{ml}$. inhibited growth during incubation for $48 \mathrm{hr}$ at $30^{\circ}$. The precise end-point varied in different experiments, but the cause of the variation was not studied further. During a typical m.i.c. determination, growth was completed within $8 \mathrm{hr}$ at $30^{\circ}$ in the medium containing penicillin at $0.00-0.15 \mu \mathrm{g} . / \mathrm{ml}$. with slight indication of growth at $0.20 \mu \mathrm{g}$. $/ \mathrm{ml}$. After a further $20 \mathrm{hr}$ of incubation, growth occurred at concentrations up to the m.i.c.

\section{Dry-weight yield and terminal $p H$ value}

A progressive decrease of dry-weight yield at $48 \mathrm{hr}$ occurred at penicillin concentrations up to $0.20 \mu \mathrm{g}$. $/ \mathrm{ml}$. There was a slight enhancement of growth at $0.25 \mu \mathrm{g} . / \mathrm{ml}$. which resulted in some increase in dry-weight yield. Above $0.25 \mu \mathrm{g} . / \mathrm{ml}$., and as the m.i.c. was approached, the dry weight again decreased (Fig. I). The terminal pH values of the cultures were inversely related to the dry weight.

\section{Nisin content}

Total and cell-bound nisin values in cultures incubated for $48 \mathrm{hr}$ at $30^{\circ}$ are shown in Fig. 1. The total nisin synthesized (per unit dry weight organism) was similar at all concentrations of penicillin. However, the cell-bound nisin (also per unit dry weight) increased as the concentration of penicillin increased from 0.00 to $0.15 \mu \mathrm{g} . / \mathrm{ml}$.; the latter cultures contained about Io times more cellular nisin than control organisms grown without penicillin. The cell nisin content was lower at $0.25 \mu \mathrm{g} . / \mathrm{ml}$., but again showed an increase to values 8 times greater than the control organisms at concentrations of penicillin immediately below the m.i.c. Following an m.i.c. estimation the organisms were harvested, resuspended in the same volume of fresh penicillin-free medium, adjusted with lactic acid to $\mathrm{pH} 4 \cdot 2$, and left standing at $30^{\circ}$ for $24 \mathrm{hr}$. The cell nisin was then again estimated and found to be unchanged. 


\section{Morphology}

The phase-contrast appearance of the organism obtained after growth for $48 \mathrm{hr}$ at the various concentrations of penicillin is shown in P1. I, fig. I to 8. The photographs show that in the presence of up to $0.20 \mu \mathrm{g}$. penicillin $/ \mathrm{ml}$. the organisms became progressively more rod shaped. Concomitant with this development they became Gramnegative. Some of the rod-shaped forms were phase dark and appeared intact, whereas

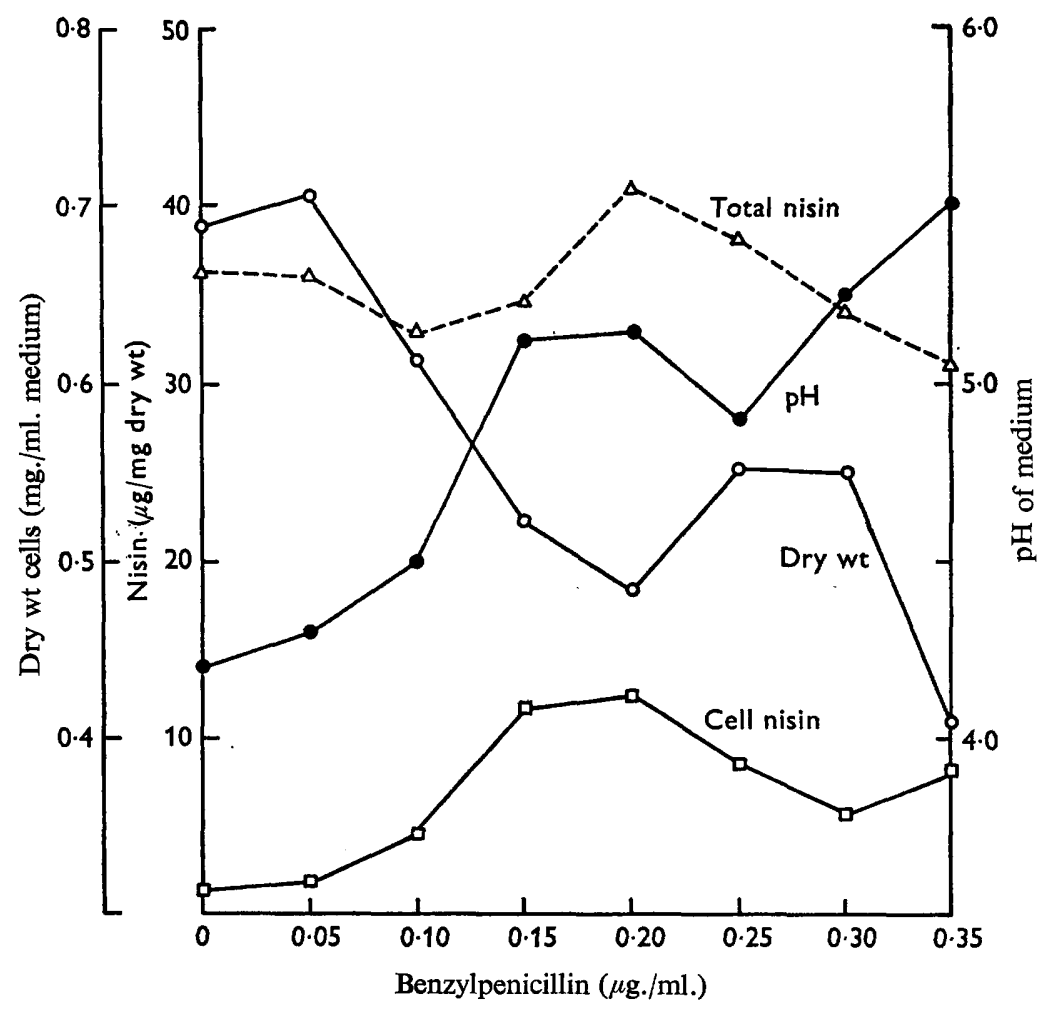

Fig. I. Effect of benzylpenicillin on the growth and biosynthetic activities of Streptococcus lactis. Estimations were made after $48 \mathrm{hr}$ growth at $30^{\circ}$.

others were ghost-like and had granules within them. In some experiments, although not all, together with these rod-shaped forms there was also a small proportion of coccobacilliary forms. In the presence of $0.25 \mu \mathrm{g}$. penicillin $/ \mathrm{ml}$. the organisms showed a marked resemblance to those grown without penicillin. At this concentration only coccobacilli developed which were mainly Gram-positive. However, at concentrations approaching the m.i.c. cell elongation took place and the organisms were Gramnegative. Together with the slight variation in actual m.i.c. encountered in different experiments the precise concentration of penicillin at which the reversion from the rod-shaped form to the coccobacillary form occurred varied slightly $( \pm 0.05 \mu \mathrm{g}$. $/ \mathrm{ml}$.). Subcultures from tubes containing rod-shaped predominately Gram-negative organisms into fresh medium without penicillin grew as normal Gram-positive coccobacilli. 


\section{Osmotic fragility}

The rod-shaped forms obtained after growth of the test organism in medium containing $0.10-0.15 \mu \mathrm{g}$. penicillin $/ \mathrm{ml}$. were not osmotically fragile because on harvesting them from the growth medium they did not burst when suspended in distilled water. They were also interesting in that many showed small bubbles or vesicles protruding from the surface of the cell (see Pl. I, fig. 4); some forms had as many as six vesicles. Vesicle formation was also observed on some forms which grew at $0.35 \mu \mathrm{g}$. penicillin $/ \mathrm{ml}$. Electron micrographs of fixed and sectioned organisms showed that the vesicles were formed by the extrusion of membrane through a damaged point of the cell wall (see Pl. 2, fig. 9).

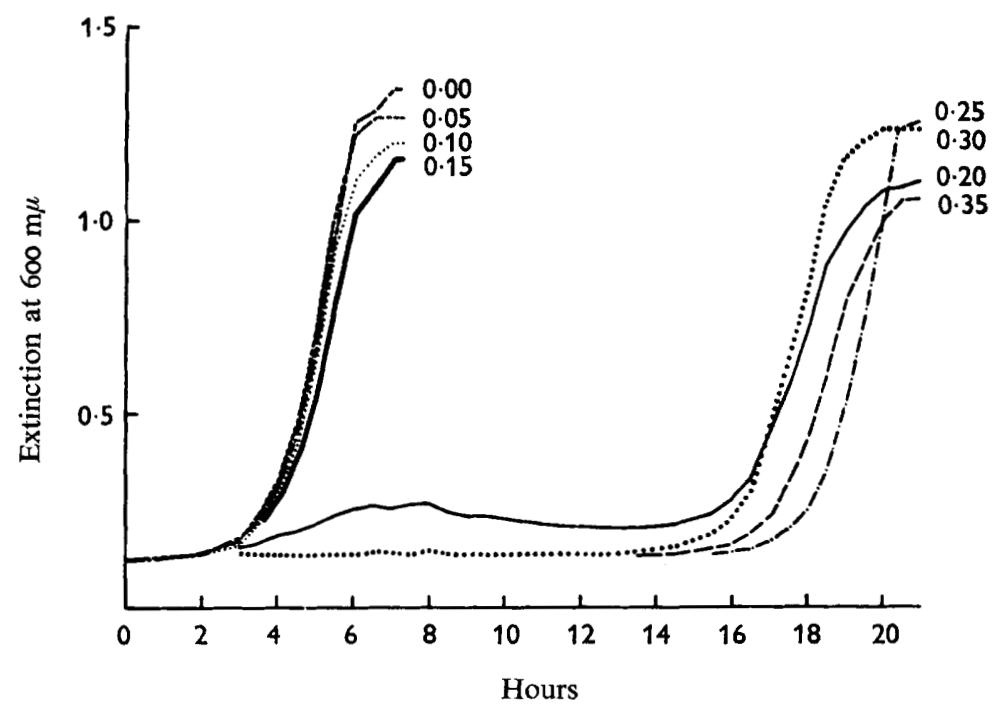

Fig. 2. Growth curves of Streptococcus lactis in various concentrations of benzylpenicillin showing development of two populations from the parent culture. Figures 0.00 to 0.35 show concentrations of penicillin $(\mu \mathrm{g} / \mathrm{ml}$.) used.

\section{Effect of penicillin on growth kinetics}

The growth cycles of the organism cultured at the various concentrations of penicillin $(0.05$ to $0.35 \mu \mathrm{g} . / \mathrm{ml}$ ) were then studied (Fig. 2). Initiation of growth in cultures in medium containing penicillin 0.00 to $0.15 \mu \mathrm{g} . / \mathrm{ml}$. occurred after a lag period lasting about $2 \mathrm{hr}$ and these low concentrations of penicillin had little effect on the rate of growth. After $4 \mathrm{hr}$ of incubation growth started in medium containing 0.20 to $0.25 \mu \mathrm{g}$. penicillin $/ \mathrm{ml}$. The rate of growth was much slower than at the lower concentrations of penicillin and continued up to 6 to $7 \mathrm{hr}$, after which the extinction value decreased. Examination of hanging-drop preparations under phase contrast showed that lysis was occurring at this time. After a prolonged delay of 14 to $16 \mathrm{hr}$, growth began again. At penicillin concentrations of 0.30 to $0.35 \mu \mathrm{g}$. $/ \mathrm{ml}$. there was no intermediate growth and lysis; growth started after a delay of $16 \mathrm{hr}$. Once started the growth rate was the same at all penicillin concentrations from 0.20 to $0.35 \mu \mathrm{g}$. $/ \mathrm{ml}$. Nisin synthesis in a control culture and one growing in medium containing $0.15 \mu \mathrm{g}$. penicillin $/ \mathrm{ml}$. began when some $50 \%$ of the total organism dry weight had been formed. Elongation to long 
forms in medium containing penicillin was observed as soon as growth began. There was thus no correlation between elongation and the increase in cell-nisin content.

\section{Isolation of type II cultures}

The effect of increasing concentrations of penicillin on stationary phase organisms was discontinuous in that intermediate concentrations of penicillin caused unexpected changes in morphology, dry weight, terminal $\mathrm{pH}$ value and cellular nisin content. For example, penicillin at $0.20 \mu \mathrm{g}$. $/ \mathrm{ml}$. initially permitted growth which after lysis was followed by further growth. These results clould be most easily explained by assuming that the parent population was heterogeneous as regards the penicillin resistance of individuals. Accordingly, organisms from medium containing 0.30 and $0.35 \mu \mathrm{g}$. penicillin $/ \mathrm{ml}$. were subcultured to fresh medium without penicillin and incubated overnight. The cultures were streaked on agar and single colonies were isolated and grown in penicillin-free liquid medium. Their response to graded amounts of penicillin $(0.05$ to $0.40 \mu \mathrm{g}$. $/ \mathrm{ml}$.) was then tested. The discontinuous effect observed with the parent culture could not be reproduced; the m.i.c. was $0.40 \mu \mathrm{g}$. penicillin $/ \mathrm{ml}$. after only overnight incubation. These were called type II cultures; their response when challenged by graded amounts of penicillin was not altered by up to five daily serial subcultures in penicillin-free medium.

The type II cultures differed from the parent population in that the organisms, although of coccobacillary morphology, were slightly larger than normal. There was a small, but consistent difference between the terminal $\mathrm{pH}$ values of the type II cultures $(\mathrm{pH} 4.5)$ and the parent cultures $\left(\mathrm{pH}_{4} \cdot 2\right)$. When grown in the absence of penicillin, the total and cell nisin synthesized by the type II culture were the same as those of the parent population; the growth rates were also the same.

The parent population thus consisted of a majority of individuals which could grow in liquid medium broth up to $0.15 \mu \mathrm{g}$. penicillin $/ \mathrm{ml}$; ; at penicillin concentrations of 0.20 to $0.35 \mu \mathrm{g}$. $/ \mathrm{ml}$. only type II individuals grew. The frequency of occurrence of type II individuals in the parent population was tested by most probable number counts (m.p.n.). Total numbers were estimated by growing in liquid medium alone and type II numbers by growing in liquid medium containing $0.25 \mu \mathrm{g}$. penicillin $/ \mathrm{ml}$. Type II organisms were $\mathrm{I} / 500$ of the parent population. Counting on nutrient agar media gave similar results.

That a hitherto 'pure' culture of Streptococcus lactis should harbour two strains, the progeny of which could be readily screened on the basis of their relative resistance to penicillin, prompted studies to determine whether the type II organisms possessed other characteristics distinguishable from the parent population. The heat resistance of type II organisms and the parent population were tested and found to be the same.

The effect of suspending organisms in distilled water and $0.04 \mathrm{~N}$-lactic acid was also tested and the results subjected to analysis of variance. One hr in distilled water at $37^{\circ}$ did not alter the number of organisms as revealed by surface plate counts. Replication of these colonies on agar containing increasing concentrations of penicillin showed that 0.3 to $0.5 \mu \mathrm{g} . / \mathrm{ml}$. did not affect the number of colonies able to develop (Table I). However, $0.04 \mathrm{~N}$-lactic acid caused a $99 \%$ kill, as revealed by surface plate counts. Replication of these colonies on agar containing increasing concentrations of penicillin showed, as before, that the number of colonies which developed was independent of the penicillin concentration $(0.3$ to $0.5 \mu \mathrm{g}$. $/ \mathrm{ml}$.). The initial $\mathrm{F}$ value for this distribution 
at the $5 \%$ level was $4.4 \mathrm{I}$ and the value found of $2.5 \mathrm{I}$ was therefore not significant. On the other hand, comparison of the number of colonies developing at the different penicillin concentrations revealed a highly significant difference between the two treatments (distilled water and lactic acid). The initial value of the $F$ distribution at the $1 \%$ level was 8.29 ; the value found was 12.34 and was therefore highly significant. These results show that the lactic acid treatment selected a homogeneous population which was significantly different from the parent population by its penicillin resistance.

Table 1 . The selection of penicillin resistant colonies by lactic acid

Overnight cultures of Streptococcus lactis 354/07 (NCDO 497) were centrifuged, the deposit washed once with distilled water and suspended at $10^{7}$ organisms $/ \mathrm{ml}$. in distilled water or in $0.04 \mathrm{~N}$-lactic acid at $37^{\circ}$ for $\mathrm{I} \mathrm{hr}$. Survivors were then counted by surface plating and resulting colonies screened for penicillin resistance.

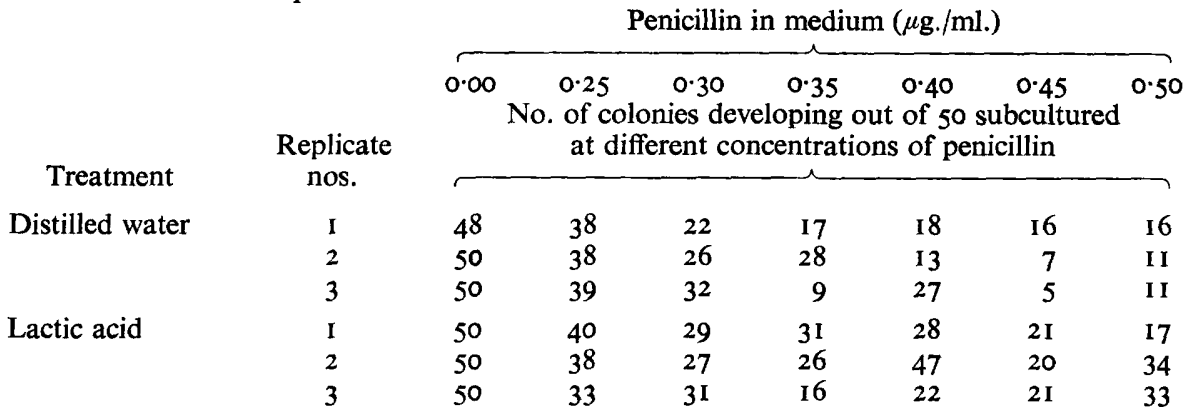

\section{DISCUSSION}

On the basis of penicillin resistance two strains could be distinguished in a culture of Streptococcus lactis which was known to be otherwise pure, and which explained the discontinuous growth response of the culture to penicillin. Cultures which were inhibited by concentrations of penicillin of 0.15 to $0.20 \mu \mathrm{g}$. $/ \mathrm{ml}$. were designated type $\mathrm{I}$, and those inhibited by 0.35 to $0.40 \mu \mathrm{g}$. $/ \mathrm{ml}$. type II. Penicillin probably acted by selecting the resistant individuals already in the parent population. Once isolated from single colonies, type II cultures retained their higher penicillin resistance when grown in the absence of penicillin. Based on penicillin resistance type II organisms formed $\mathrm{r} / 500$ of the population. The results of the tests with lactic acid confirmed that type II organisms were present in the parent population before contact with penicillin. However, this test did not tell us how many of the lactic acid resistant organisms were also penicillin resistant.

Comparison of type II cultures with the parent population showed that the former differed in that they had a higher terminal $\mathrm{pH}$ value in cultures and tended to be larger. The latter property could be due to an over-all increase in size or to a change in cellwall thickness. The experiment in which organisms surviving lactate were also more penicillin resistant suggests that type II organisms may have an altered surface structure, causing changes in the permeability characteristics. Such effects were particularly evident when Streptococcus lactis was grown in sublethal amounts of penicillin. For example, Hurst \& Dring (I968) showed that the percentage of nisin retained by the producer organism was $\mathrm{pH}$ dependent; at $\mathrm{pH}>6.0$ more than $80 \%$ of the nisin was cellular, whereas at $\mathrm{PH}<6.0$ more than $80 \%$ of the nisin was in the medium. The data 
of Fig. I have been replotted in Fig. 3 and show that in the presence of penicillin the distribution of nisin was no longer dependent on $\mathrm{pH}$ value but on the concentration of penicillin in which the organism had been grown. Rogers (1967) showed that when Staphylococcus aureus was grown in penicillin, membrane permeability was affected.

Various studies have been made of intracellular membranous structures or mesosomes in bacteria (Gel'man, Lukoyanova \& Ostrovskii, 1967). Fitz-James (1964), Ryter \& Landman (1964) and Kakefuda, Holden \& Utech (1967) showed the association of mesosomes with the cell membrane in various bacteria. Fitz-James (1964) and

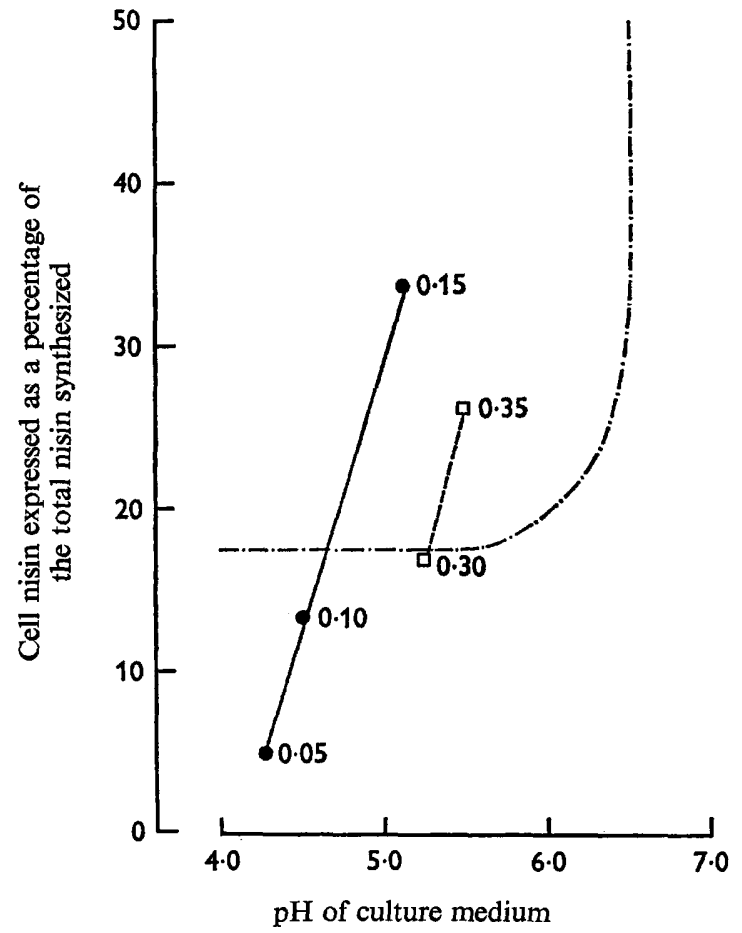

Fig. 3. The effect of benzylpenicillin at various concentrations on the synthesis and binding of nisin by Streptococcus lactis. Organism grown without penicillin showing the binding of cell nisin as a function of the $\mathrm{pH}$ of the medium. Data from Hurst \& Dring (I968) -...-. -; cell-bound nisin of type I cells growing in 0.05 to $0.15 \mu \mathrm{g}$. penicillin $/ \mathrm{ml}$., nisin of type II cells growing in 0.30 and $0.35 \mu \mathrm{g}$. penicillin $/ \mathrm{ml}, \square \ldots-. \square$.

Ryter \& Landman (1964) showed that such mesosomes were extruded into the wallmembrane interspace (periplasm) during protoplast formation and that they were released into the medium when the cell wall was ruptured. Plate I, fig. 4, and Pl. 2, fig. 9, probably depict the same phenomenon of mesosome extrusion when the cell wall of Streptococcus lactis was damaged by penicillin. Although the vesicles (P1. 2, fig. 9) appeared to be bounded only by membrane they were not osmotically fragile. If the retaining structure of the vesicle were solely a lipoprotein membrane, then lysis of the vesicle would have been expected. As this did not occur it is possible that a strengthening, although non-rigid, layer was also present. Fitz-James (1964), from the appearance of Bacillus megaterium mesosomes as shown by electron microscopy, suggested that they consisted of vesicles with associated wall-like material. White \& Hurst (1968) were 
unable, by using mechanical means, to prepare a membrane fraction from $S$. lactis free from amino sugar and suggested that the cell wall and membrane of this organism formed a closely integrated structure. The presence of the stable extruded vesicles is in accordance with these suggestions. Briggs, Crawford, Abraham \& Gladstone (I957) obtained results with Staphylococcus aureus which were similar to ours. However, later work cast doubt on the original findings, suggesting that the results were due to contamination (Hilson \& Elek, 1959). If in our study twofold increments in penicillin concentrations had been used, which are customary in m.i.c. determinations (Briggs et al. 1957) the stable type II population might have been missed. It is possible that this accounts for the failure of some workers to reproduce the conditions necessary for the isolation of two forms of Staphylococcus aureus.

The authors wish to thank Mr J. M. Stubbs, who did the electron microscopy, Mr I. W. Tully for statistical analysis and Mr M. E. Pugh for technical assistance.

\section{REFERENCES}

Briggs, S., Crawford, K., Abraham, E. P. \& Gladstone, G. P. (1957). Some properties of Gramnegative bacilli obtained from a strain of Staphylococcus aureus in the presence of benzylpenicillin. J. gen. Microbiol. 16, 6I4.

BRown, W. C., SANDine, W. E. \& Elliker, P. R. (1962). Lysis of lactic acid bacteria by lysozyme and ethylenediaminetetraacetic acid. J. Bact. 83, 697.

DRING, G. J. \& HURST, A. (1967). The effect of penicillin on a nisin-producing strain of Streptococcus lactis. Biochem. J. 106, 45 P.

FITZ-JAMEs, P. C. (1964). Fate of the mesosomes of Bacillus megaterium during protoplasting. J. Bact. 87,1483 .

Gel'man, N. S., Lukoyanova, M. A. \& Ostrovskin, D. N. (1967). In Respiration and Phosphorylation of Bacteria. Ed. by G. B. Pinchot. New York: Plenum Press.

Hamilton, W. A. \& StubBs, J. M. (1967). Comparison of the germination and outgrowth of spores of Bacillus cereus and Bacillus polymyxa. J. gen. Microbiol. 47, I2I.

Hirson, G. R. F. \& ElEK, S. D. (1959). An investigation into the development of Gram-negative rods in penicillin-treated cultures of Staphylococcus aureus. J. gen. Microbiol. 2r, 208.

Hurst, A. (I966). Biosynthesis of the antibiotic nisin by whole Streptococcus lactis organisms. J. gen. Microbiol. 44, 209.

HURST, A. \& DRING, G. J. (1968). The relation of the length of the lag phase of growth to the synthesis of nisin and other basic proteins by Streptococcus lactis grown under different cultural conditions. J. gen. Microbiol. 50, 383 .

KAKEFUDA, T., Holden, J. T. \& UTECH, N. M. (1967). Ultrastructure of the membrane system in Lactobacillus plantarum. J. Bact. 93, 472.

MAXTED, W. R. (1948). Preparation of streptococcal extracts for Lancefield grouping. Lancet, ii, 255.

MCQuillen, K. (1960). Bacterial Protoplasts. In The Bacteria. Ed. by I. C. Gunsalus and R. Y. Stanier. Vol. I. New York: Academic Press.

MiLes, A. A. \& MisRA, S. S. (1938). The estimation of the bactericidal power of the blood. J. Hyg., Camb. 38, 732.

RoGERs, H. J. (1967). Killing of staphylococci by penicillins. Nature, Lond. 213, 31 .

RYTER, A. \& LANDMAN, O. E. (I964). Electron microscope study of the relationship between mesosome loss and the stable L state (or protoplast state) in Bacillus subtilis. J. Bact. 88, 457.

WhIte, R. J., \& HURST, A. (I968) The location of nisin in the producer organism, Streptococcus lactis. J. gen. Microbiol. (in the Press). 


\section{EXPLANATION OF PLATES \\ Plate I}

Fig. 1-8. Morphology of stationary phase whole Streptococcus lactis grown in medium containing $0.00,0.05,0.10,0.15,0.20,0.25,0.30$ and $0.35 \mu \mathrm{g}$. penicillin/ml. Phase contrast: $\times 2000$ (approx.). Note vesicle formation (arrowed) in $0.15 \mu \mathrm{g}$. penicillin $/ \mathrm{ml}$.

\section{Plate 2}

Fig. 9. Section of vesicle on a Streptococcus lactis organism grown in $0.15 \mu \mathrm{g}$. penicillin $/ \mathrm{ml} . \times 60000$. 
Journal of General Microbiology, Vol. 55, No. 2

Plate I
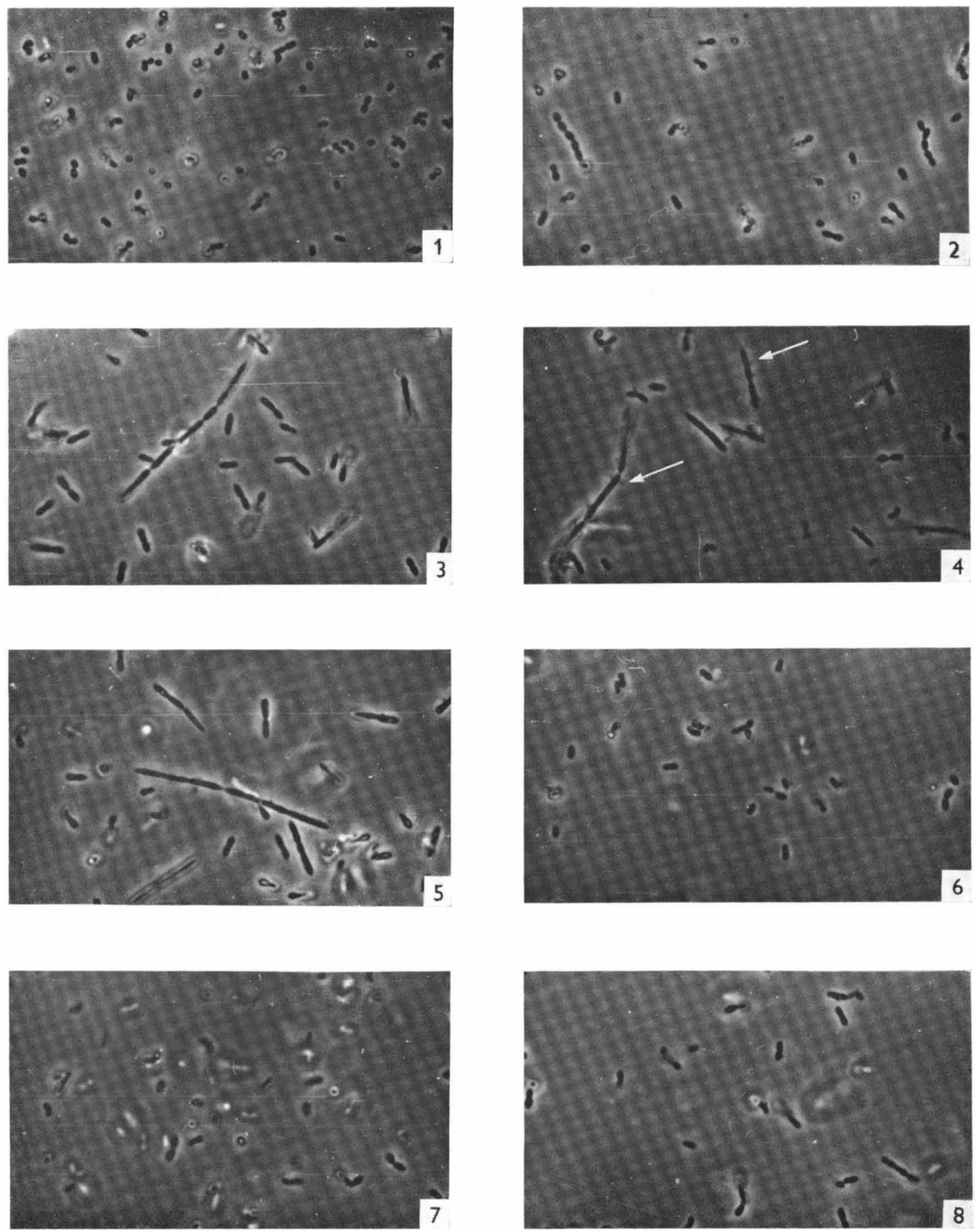

G. J. DRING AND A. HURST

(Facing p. 194) 


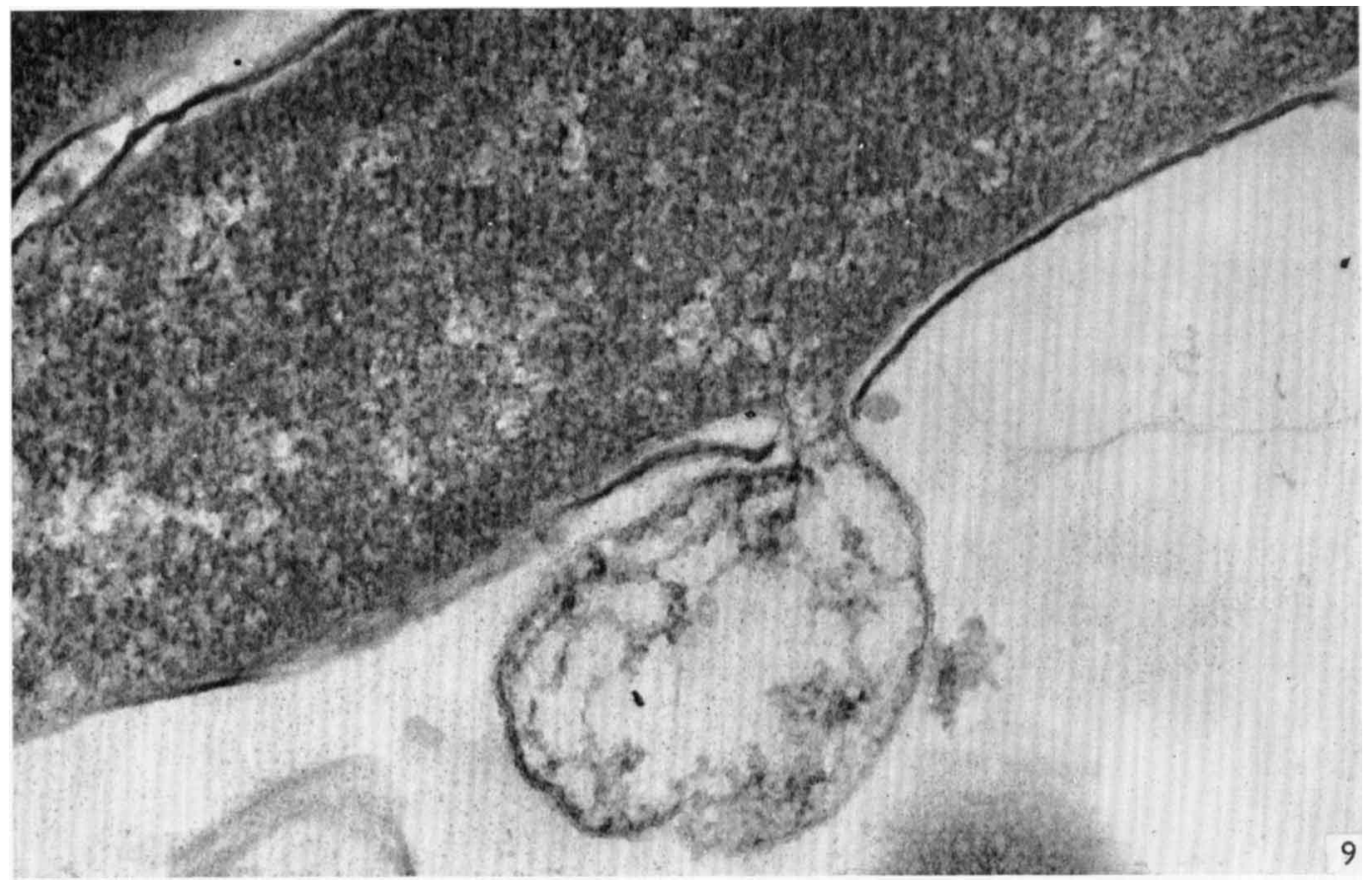

